\title{
Interest, media use, and participation in the 2019 Spanish election campaign
}

\author{
Ana Castillo-Díaz; Antonio Castillo-Esparcia
}

Nota: Este artículo se puede leer en español en:

http://www.profesionaldelainformacion.com/contenidos/2021/nov/castillo-castillo_es.pdf

\section{How to cite this article:}

Castillo-Díaz, Ana; Castillo-Esparcia, Antonio (2021). "Interest, media use, and participation in the 2019 Spanish election campaign". Profesional de la información, v. 30, n. 6, e300607.

https://doi.org/10.3145/epi.2021.nov.07

Manuscript received on May $28^{\text {th }}, 2021$ Approved on October $12^{\text {th }}, 2021$

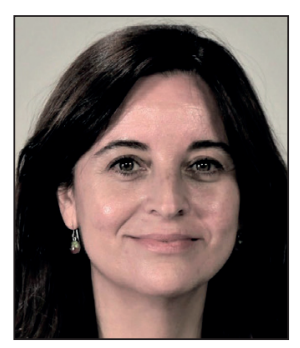

Ana Castillo-Díaz $\bowtie$ https://orcid.org/0000-0002-3650-2964

Universidad de Málaga

Departamento de Comunicación

Audiovisual y Publicidad

Campus de Teatinos, $\mathrm{s} / \mathrm{n}$

29071 Málaga, Spain

anacastillo@uma.es

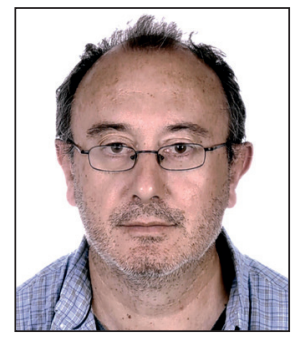

\section{Antonio Castillo-Esparcia}

https://orcid.org/0000-0002-9751-8628

Universidad de Málaga

Departamento de Comunicación

Audiovisual y Publicidad

Campus de Teatinos, $\mathrm{s} / \mathrm{n}$

29071 Málaga, Spain

acastilloe@uma.es

\begin{abstract}
This work analyzes the relationships between interest in the campaign for the 2019 Spanish general elections, the type of media used to follow it, and participation through conversations, disseminating electronic messages about the elections, and voting. A secondary data analysis of surveys published by the Spanish Centre for Sociological Research (CIS) is carried out. The existence of relationships between the variables is determined by using the chi-squared hypothesis test, while the strength of the associations is measured by means of the Cramér's $V$ and the contingency coefficient. Trends are examined by analyzing the conditioned relative frequencies. The results show a strong association between interest in the campaign and the type of medium chosen to obtain information. Likewise, there is a remarkable relationship between the interest of voters and their participation in conversations, especially in family environments, and in the dissemination of digital information about the elections. In contrast, the candidates' arguments and pledges are not significantly related to the reason for voting. Similarly, demographic variables are weakly related with interest in the campaign, following it on the media, and participation by voting, with educational level being the only characteristic exhibiting moderately strong associations.
\end{abstract}

\section{Keywords}

Political communication; Political campaigns; Electoral campaigns; Political debates; Media; Use of media; Informational interest; News monitoring; Citizen participation; Political participation.

\section{Introduction and background}

Information about political campaigns attracts special interest from citizens. In general terms, following information on a certain matter can favor the formation of a more consistent opinion on it. Following this argument, one can ask whether there is a relationship between the interest in following a political campaign and the type of medium chosen to obtain such information. The answer to this question, the first research question of the present work, offers an interesting key to determine the level of trust that citizens place in different types of media when following political news. In the case of television, a medium that tends to have a broad public following, including those who do not consult any other type of source, debates among candidate are of particular interest.

Beyond the reception of information, it is worth asking the second research question in this study, i.e., whether there are links between interest in campaigns, the information followed, and political participation at different levels, be that through conversations on election topics, sending or forwarding related content through digital media, or ultimately voting. 
Specifically, this research focuses on an analysis of the link between the degree of interest in following information about the 2019 general election campaign in Spain, the type of medium used to learn about the proposals in the candidates' program, and citizen participation in conversations about the elections, spreading of related content, and participation through voting. The distribution of sociodemographic factors (gender, age, and educational level) provides a more detailed description of the possible associations.

A secondary data analysis is carried out by applying statistical methods to the results of surveys published by the Centre for Sociological Research (Barometer of December 2019).

\subsection{Political participation and the media as information sources}

The media, as one of the main information sources for citizens, act as intermediaries in the relationship between citizens and political processes. People usually receive information about politics through the media rather than directly from political agents (Soroka; Wlezien, 2019). Media coverage thus influences the perception of citizens on political issues (Walgrave; Soroka; Nuytemans, 2008; Müller, 2020, p. 698) and affects the formation of opinions and voting decisions (Strömbäck, 2008; Druckman; Parkin, 2005). The media also have an obvious control function when deciding which content is newsworthy (Soroka, 2012). It has also been shown that there is a positive link between media use and political trust (Strömbäck; Djerf-Pierre; Sehata, 2016).

In recent decades, political communication systems have undergone a profound change (Van-Aelst et al., 2017). On the one hand, the growing proliferation of digital media has facilitated both access to voters and the dissemination of political messages (Madianou; Miller, 2013). On the other hand, from the receivers' point of view, there has been an expansion in the possibilities of receiving information and of interactivity, enhancing the options for citizen participation.

According to the theory of selective exposure (Lazarsfeld; Berelson; Gaudet, 1948), the current panorama favors audience fragmentation, creating niches based on ideological and political positions (Humanes, 2014). Beyond the affirmations of that theory, political interest is an important predictor of media use (Hopmann et al., 2016). Correlations between interest in politics and attention to related news have been identified (Strömbäck; Shehata, 2010), as well as causal and reciprocal associations in the case of public television (Strömbäck; Shehata, 2019). However, the relationship between citizens' interest in politics and their following of information is a field that has yet to be explored sufficiently.

Some research has indicated that following the news is related to political participation, as it can offer information that serves as a basis for mobilization (Kaufhold; Valenzuela; Gil de Zúñiga, 2010). These effects are in line with the virtuous circle described by Norris (2000), who argues that media coverage of politics contributes to increasing knowledge as well as motivation to participate actively. Two of the most basic forms of citizen participation in electoral processes are voting or simply talking about political issues (Moeller et al., 2014; Cho et al., 2009). In addition, it is common today for citizens to send and forward content, usually through digital means, thereby sharing opinions on politics and current events (Weeks et al., 2017).

In this regard, instant messaging plays a prominent role as a tool to receive and share political content (Pont-Sorribes; Besalú; Codina, 2020). People who frequently discuss politics tend to present higher levels of political knowledge and interest, in turn influencing their level of interest in politics (Gil de Zúñiga; Ardèvol-Abreu; Casero-Ripollés, 2019). It is reported that the content underlying participation generally comes from current affairs (Ardèvol-Abreu; Barnidge; Gil de Zúñiga, 2017), with content offered by professional media outlets being the fundamental raw material for such interactions (Mondak, 2010, p. 94).

\subsection{The media and political campaigns: staying informed and participation}

Campaigns, as part of political communication, play a relevant role in democratic systems in terms of the relationship between politicians and citizens (Benoit, 2017). They can contribute to increasing opportunities for deliberation and more informed choices by citizens (Ackerman; Fishkin, 2004).

Although individuals' own experiences determine how they evaluate information in a political campaign, the important role played by the media in developing a shared framework about the campaign cannot be ignored (Strömbäck; Dimitrova, 2011; Vinson; Moore, 2007, p. 394), as it helps voters become more aware of the differences between the alternatives presented (Müller, 2020). Although news media may highlight certain issues and present diverse representations of candidates (Druckman; Parkin, 2005, p. 1030), the limited budgets of political parties, together with the possibility offered by the media to spread their message among very specific target audiences, make media access crucial for them (Gerth; Siegert, 2012, p. 280).

During campaigns, debates constitute an element that tends to be of particular interest to the public (Gottfried et al., 2017, p. 174), Despite the gradual decrease in their audiences (González-Neira; Berrocal-Gonzalo; Zamora-Martínez, 2020), they feature the main candidates discussing issues of interest, which can help voters decide whom to vote for and foster political discussion (Benoit; Benoit-Bryan, 2013, p. 464).

Since Lazarsfeld, Berelson and Gaudet (1948) analysis of the media's role in elections, numerous investigations have focused on this relationship, studying the influence of the media through their news coverage of campaigns. In this regard, 
the studies by Drew and Weaver (2006) suggest that following television news, debates, and the Internet is related to how voters learn about candidates' proposals as well as their interest in the campaign. Norris (2000) argues that people who follow information about campaigns have a greater predisposition to activism and participation through voting.

The complexity of the motivations for participation implies that their analysis must be multifactorial, since individuals participate in political activity starting from the base of their reference group (Boulianne, 2018; Copeland; Feezell, 2017). All this indicates a greater diversity in the modes and forms of political participation, as well as a growing complexity as the segmentation of audiences and interests enabled by social media multiplies the intersubjective relationships based on concurrent political interests among group members.

Against this background, although links between political interest, media information consumption, and participation have been identified, further work is needed to holistically address political interest in an electoral campaign and staying informed about it by following different media, as well as their possible relationship with participation through conversations, disseminating information, and voting. Such work is especially interesting in Spain, where most previous studies have focused on only some of these variables (González-Neira; Berrocal-Gonzalo; Zamora-Martínez, 2020; Fontenla-Pedreira; Rúas-Araujo; Puentes-Rivera, 2020; López-García et al., 2018; Casero-Ripollés; Feenstra; Tormey, 2016; Lago-Váquez et al., 2016; Baumgartner; Chaqués-Bonafont, 2015; Fraile, 2011).

\section{Materials and methods}

A study with a quantitative methodology was carried out by applying statistical analyses to data from the barometer survey by the Centre for Sociological Investigation after the 2019 Spanish general elections.

The sample comprised 4804 people older than 18 years living in Spain. The sampling procedure was multistage, with stratified proportional random selection of the primary (municipalities) and secondary (sections) sampling strata, and of the last stratum (individuals) based on random paths and gender and age quotas. The barometer presents, for a (two sigma) confidence level of $95.5 \%$ and $P=Q$, a real error of $\pm 1.4 \%$ for the whole sample under the assumption of simple random sampling.

Based on the questions in the survey questionnaire that were related to the subject of this work, the following variables were generated:

- The degree of interest in following the general election campaign.

- The sources used to learn about the November 2019 general elections.

- Watching television debates between the general election candidates.

- Changes of voting intention after televised general election debates.

- Frequency of talking about the general elections in different social settings.

- Sending personal electronic messages related to a political party involved in the elections.

- The main reason for voting in the general elections.

- Demographic variables (gender, age, and educational level).

The responses to these questions were analyzed to evaluate whether there was an association between interest in following the 2019 Spanish general election campaign and the type of media through which citizens stayed informed. In addition, the citizens' own participation as transmitters of messages related to the content of the campaign was evaluated with respect to their degree of interest. On the one hand, the possible relationship between the respondents' interest in such information and their conversations about the elections in their own family or professional contexts was examined. On the other hand, the possible association between interest in this information and sending electronic messages with content about a party involved in the electoral process was also studied. Additionally, the possible impact of arguments presented during the political campaign on citizens' participation by voting was also investigated. These arguments were one of the reasons for voting evaluated by the barometer, together with options such as preventing other parties from winning (right-wing parties, left-wing parties, or parties in favor of independence for Catalonia) and other variables (not specified).

Moreover, the possible effects of gender, age, and educational level (Hansen; Pedersen, 2014, pp. 307-308) on the associations found between the degree of interest in the campaign, keeping abreast of information, and participation were also considered.

The question about the degree of interest in following the 2019 general election campaign had five possible responses: a lot of interest (1), some interest (2), little interest (3), no interest (4), and not reported (5), using an ordinal variable. The strength of the relationship between such variables cannot be analyzed using correlation coefficients, which only make sense when at least one variable is an interval or ratio. Furthermore, other variables in the study (e.g., gender) are nominal. Therefore, it is inappropriate to analyze the degree of relationship between these types of variables using correlation coefficients, since an increase in such a variable (e.g., gender) is unrelated to the phenomenon it represents. This fact is well illustrated by analyzing the dataset proposed by Anscombe (1973, pp. 17-21).

The chi-squared hypothesis test was applied to study the associations between the degree of interest in following the campaign, the type of media followed, and participation through conversations, spreading information, or voting. This test allows one to determine whether two variables are independent (i.e., there is no relationship between them). If the 
chi-squared test indicates that the variables are dependent, the strength of the association can be measured using Cramér's $V$ (Cramér, 1946) and the contingency coefficient (Gingrich, 1992). These parameters range between 0 and 1 , with 0 indicating independent variables. However, unlike the Pearson coefficient, values greater than 0.3 already correspond to strong relationships between variables, while values in the range of $0.25-0.3$ are considered acceptably strong. Moreover, values above 0.5 are considered to indicate that two variables measure the same phenomenon. The trends in the associations between variables are examined graphically by analysis of conditional relative frequencies.
The degree of interest in the 2019 Spanish election campaign shows a clear association with the use of press and television as preferred media to get information about it. This association has opposite sense in both media: while the use of press to get informed increases with the interest, the use of television exhibits the opposite trend

\section{Results}

\subsection{Analysis of the relationship between the degree of interest in following the electoral campaign and the media used to obtain information}

The chi-squared test confirmed the existence of a relationship between the variables describing citizens' interest in following the campaign and the medium chosen to obtain such information ( $p$-value $=0.000$, contingency coefficient $=$ 0.182 , Cramér's $V=0.107)$.

Graph 1 shows the relative frequencies of the media used to obtain information about the campaign. Television was the preferred medium, regardless of the citizens' degree of interest, with values above $50 \%$ at all levels of interest. Also, its trend for a greater following at lower interest levels differs from the other media. The digital press is the second most used medium, again regardless of the level of interest. A small percentage of people used radio as their preferred medium, being lower than that of social networks for most levels of interest.

Regarding (print or digital) press and radio, there is a clear relationship between following such information and the level of interest: the greater the interest, the greater the following. Regarding social networks, scarcely any association was observed, since the percentages were similar for those who showed a lot of, some, and little interest.

Regarding the second medium used for information, it is interesting to note that $20 \%$ of people reporting a lot of interest did not use any media beyond their first preference. However, this value soared to almost $50 \%$ among those who expressed little interest, and almost $80 \%$ among those with no interest. Radio, with high values as the second medium, reached percentages similar to television among people with low levels of interest. Among those with a high level of interest, the use of digital press as a second medium was notable (after radio and television), while social networks showed the opposite trend, with a greater following among less interested people, reaching practically the same percentages as television and radio.

A clear relationship was revealed between the level of watching television debates and the degree of interest in the campaign (Graph 2). This is supported by the chi-squared test ( $p$-value $=0.000$ ) as well as the contingency coefficient (0.507) and Cramér's $V$ (0.340).

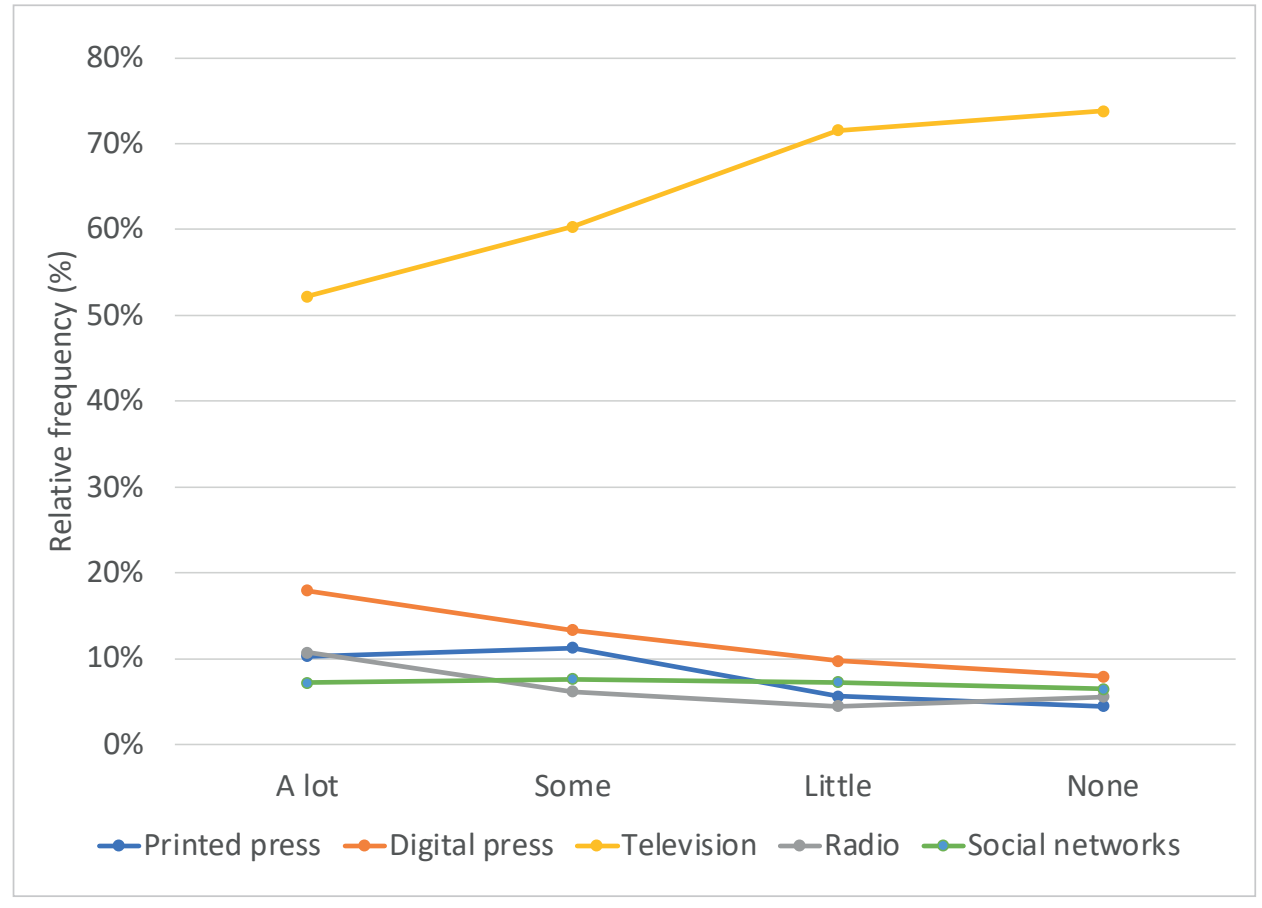

Graph 1 . The primary medium of information used versus the different degrees of interest in the campaign 


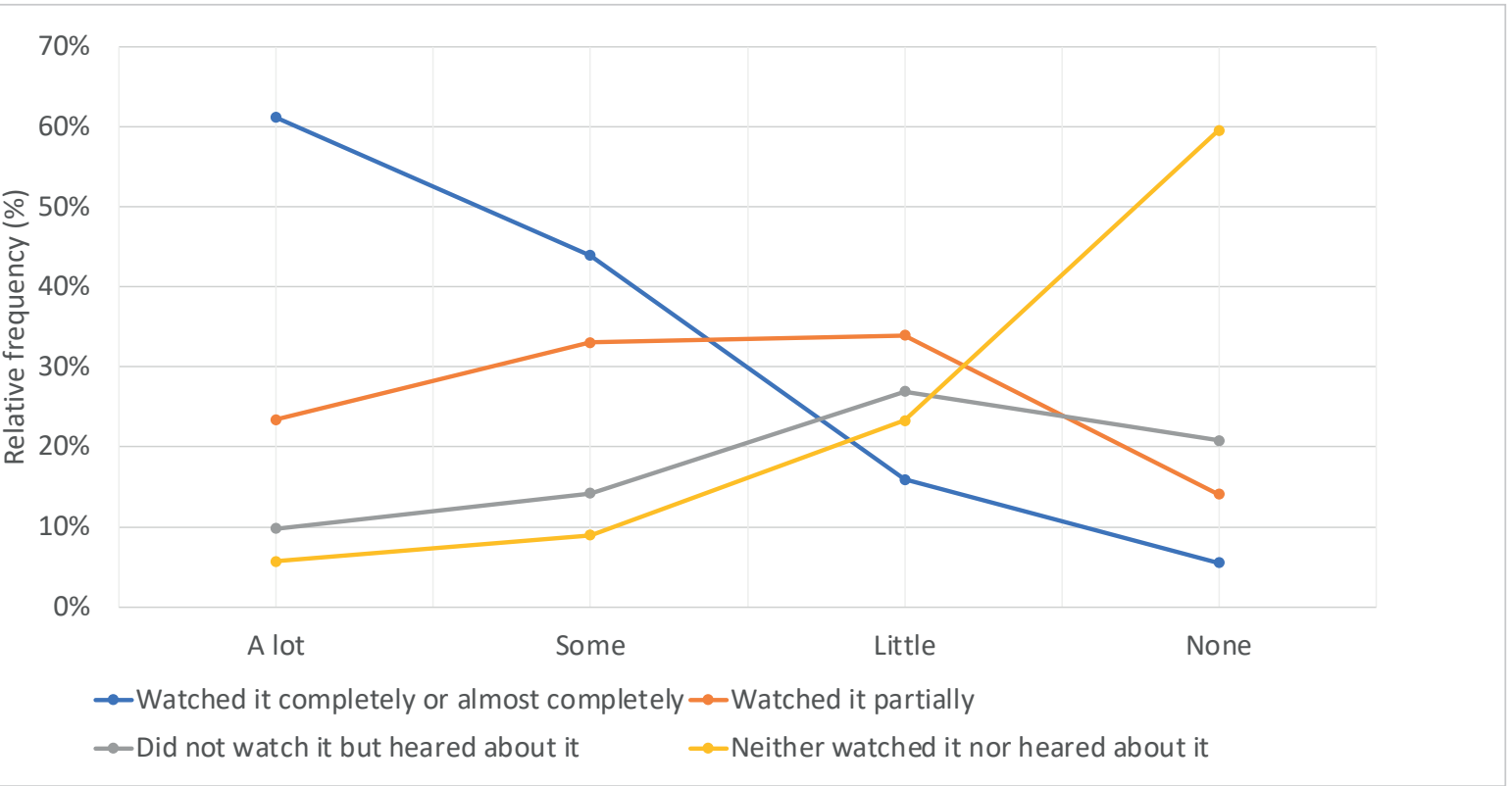

Graph 2. Following debates versus the degree of interest in the campaign

Despite the typically ample following of the election campaign debates, the results presented by the Centre for Sociological Investigation confirm that there was hardly any change in the voting intention of those who saw all or almost all the debate. Only $4.2 \%$ stated that they changed their voting intention after viewing the debate.

\subsubsection{Analysis of the relationship between demographic variables, interest in the campaign, and following news about it}

The chi-squared test ( $p$-value $=0.000$ ) as well as the relatively high values of the contingency coefficient $(0.300)$ and, to a lesser extent, Cramér's $V(0.157)$ confirmed the relationship between age and the primary medium chosen to obtain information. Television was the medium most used by all age ranges, although its percentage use increased with age. Social networks were the second most used medium by those under 25 years of age, but their use decreased with age.

In addition, there was a clear link between educational level (recoded in categories as shown in Graph 3) and interest in the campaign: the higher the educational level, the greater the interest. The chi-squared test ( $p$-value $=0.000$ ) as well as the values of the contingency coefficient $(0.234)$ and Cramér's $V(0.139)$ confirmed this. The results for the association between educational level and the media chosen to obtain information were even stronger ( $p$-value $=0.000$, Cramér's $V$ $=0.203$, contingency coefficient $=0.332$. Examining the type of media followed according to the educational level (Graph 3), one observes that television was used more frequently as the level of studies decreased. Meanwhile, the proportion of followers of other media grew with educational level, except for social networks, which were less used by university graduates than by those with a lower educational level.

The associations between gender and following information about the campaign were weaker, with coefficients below 0.143 . The weakest relationships, however, were those be-

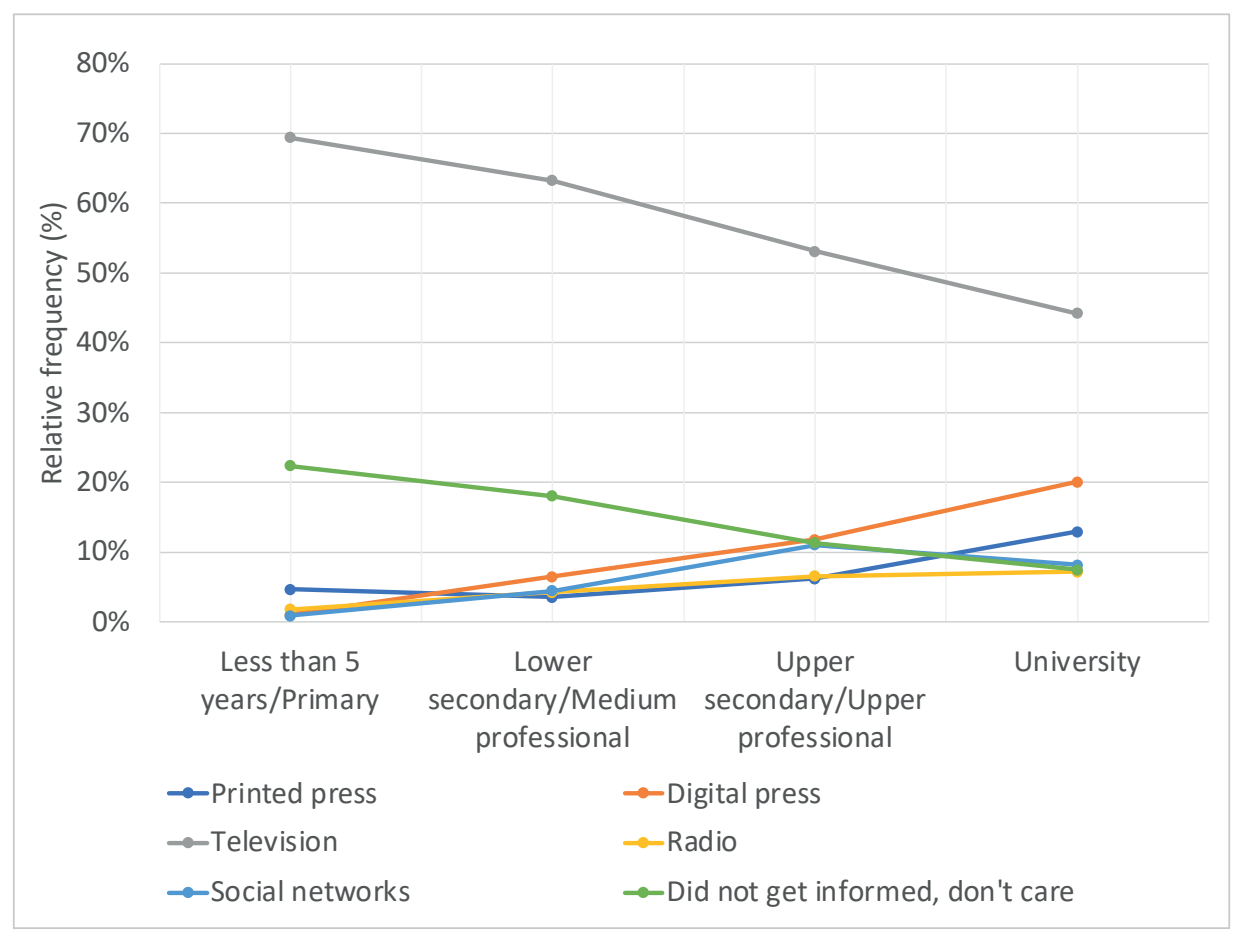

Graph 3. The primary medium used to obtain information about the elections versus educational level 


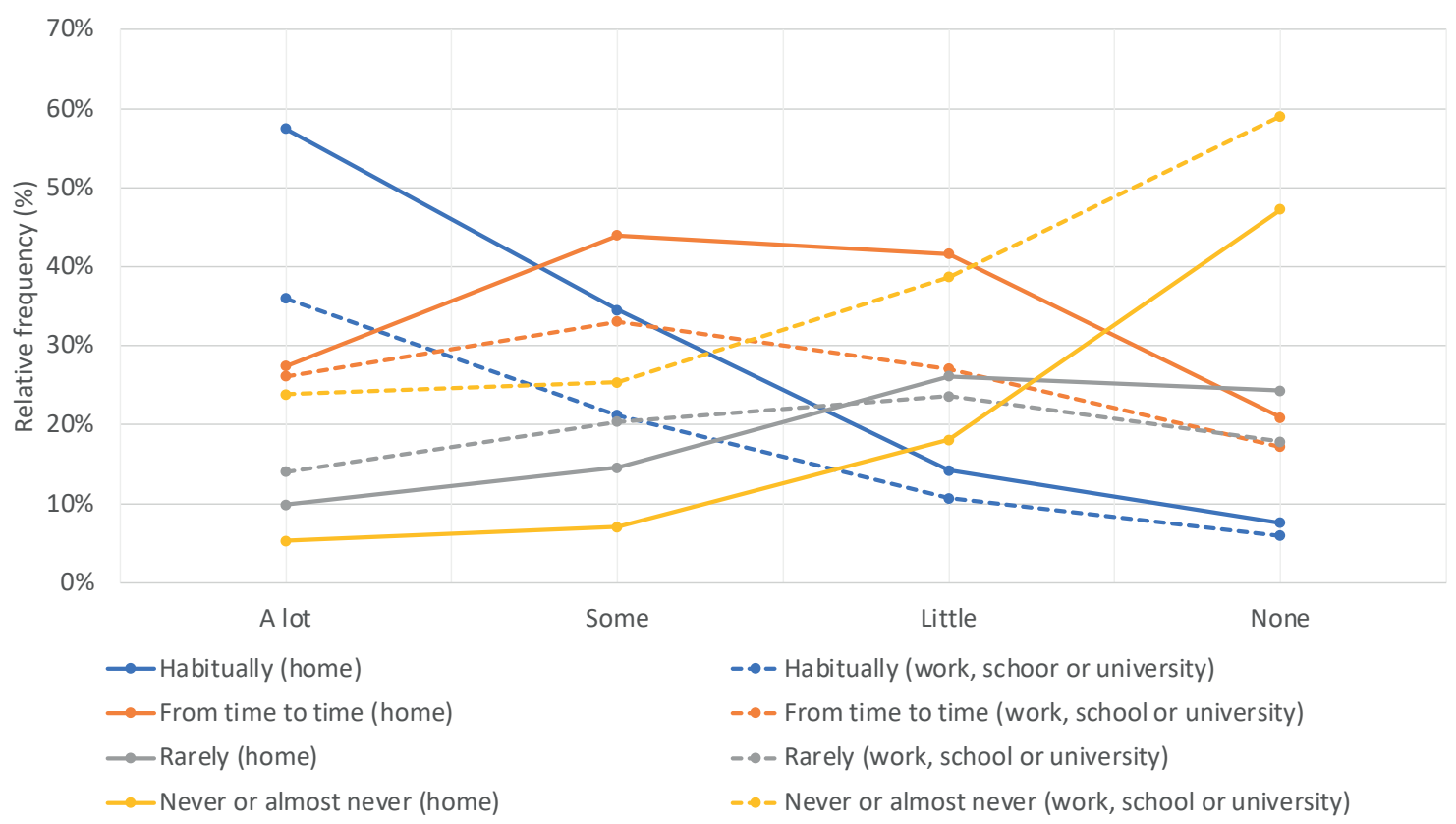

Graph 4. Frequency of conversations about the campaign versus the degree of interest in it

tween gender and interest in the campaign (Cramér's $V$, contingency coefficient $=0.110)$. Finally, insofar as demographic factors are concerned, no relationship was found between interest in the campaign and age $(p$-value $=0.101)$.

\subsection{Analysis of the relationship between degree of interest in following the electoral campaign and citizen participation: conversation, spreading information related to the campaign, and voting}

Three possible conversational contexts were considered: family, friends, and work or study colleagues. To reveal the trend regarding conversations versus the closeness of the personal relationship, Graph 4 shows a breakdown of the frequency with which respondents spoke about the election in the two contexts of greatest and least personal proximity (home, and workplace or study center). Note that, the greater the interest, the greater the participation through conversations, and that, in general, the frequency with which the election was discussed increased with increasing personal proximity. In all cases, the chi-squared test confirmed an association between the degree of interest and the frequency of such conversations ( $p$-value $=0.000$ ), while Cramér's $V$ (home 0.306 , friends 0.292 , work/studies 0.200 ) and the contingency coefficient (home 0.469 , friends 0.452 , work/studies 0.327 ) confirmed that this association was strong. Therefore, the strength of the association decreased as the distance of the relationship increased; i.e., the association was stronger at home than in the workplace or study center.

The analysis confirmed that, although the majority did not spread any type of information, there was a clear association between the degree of interest in following the campaign and spreading content about it. Among those who expressed a lot of interest, $22.8 \%$ sent content, compared with only $2.8 \%$ of those who did not show any interest. This association was supported by the chi-squared test $(p$-value $=0.000)$ and the values of the contingency coefficient $(0.213)$ and Cramér's V (0.218).

Next, the analysis of participation revealed a strong association between interest in the campaign and participation through voting ( $p$-value $=0.000$, Cramér's $V=0.278$, contingency coefficient $=0.366)$. Nonetheless, the $p$-value $(0.047)$, contingency coefficient $(0.127)$, and Cramér's $V(0.128)$ confirmed the weakness of the relationship between interest in following the campaign and the reason for voting.

\subsubsection{Analysis of the relationship between demographic variables and participation through conversations about the} campaign, spreading information, and voting

Among the demographic variables, educational level presented the most notable associations with participation. Regarding conversations, the chi-squared test confirmed a relationship with education $(p$-value $=0.000)$, while Cramér's $V$ was moderate in value (0.141). By context, a strong association was found between educational level and conversations with friends ( $p$-value $=0.000$, Cramér's $V=0.181$, contingency coefficient $=0.298$ ). Notwithstanding the differences in the frequency with

The interest in the 2019 Spanish election campaign is strongly linked to participation through voting, the frequency of conversations and the dissemination of information about it 


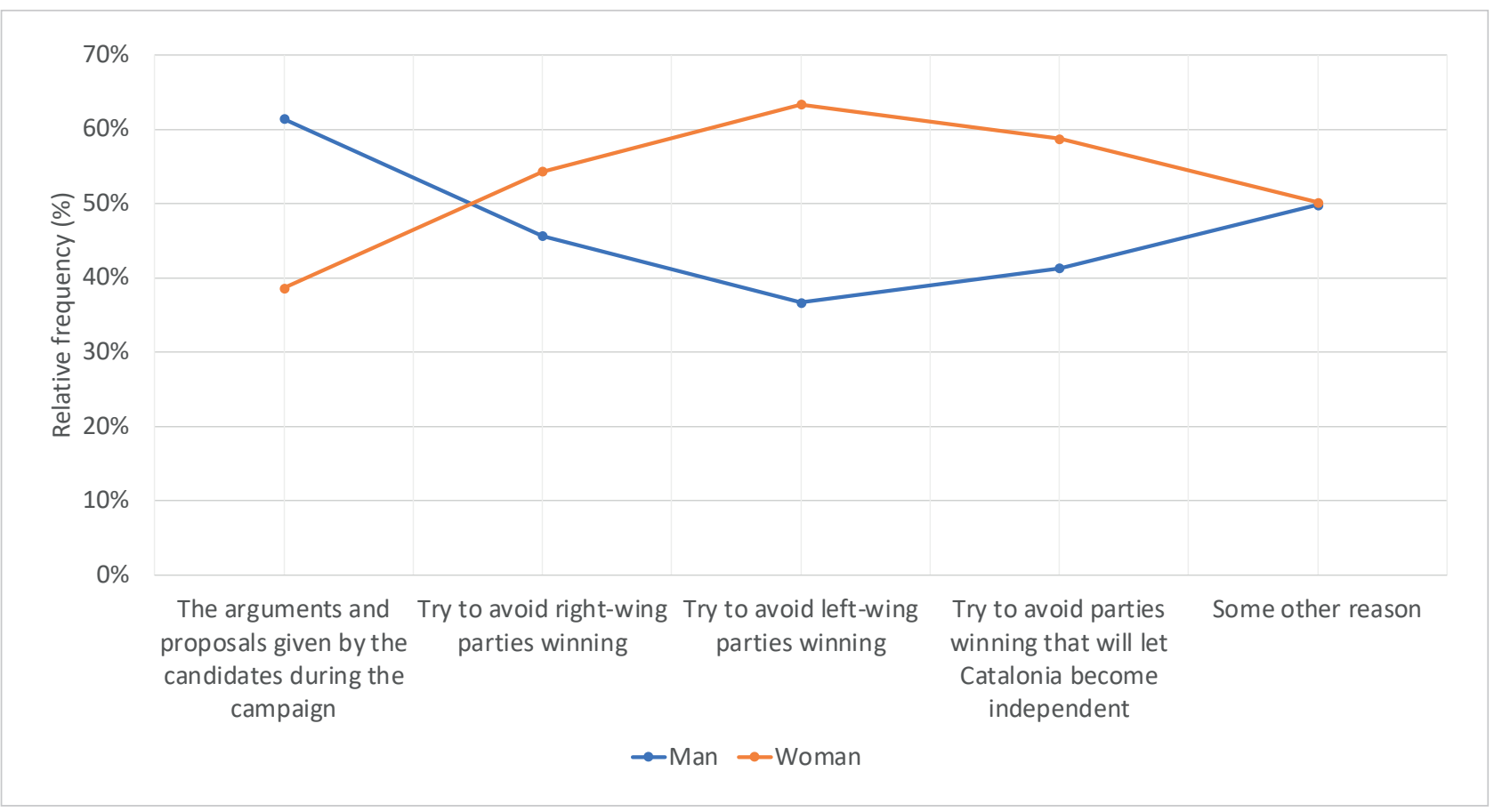

Graph 5. Reasons for voting by gender

which respondents talked about politics among the different groups, those with a higher educational level clearly talked more about politics. Beyond just conversation, educational level was also associated with spreading information: the higher the educational level, the greater the percentage of respondents who sent content. The chi-squared test confirmed this association ( $p$-value $=0.000$ ), while Cramér's $V(0.151)$ and the contingency coefficient $(0.149)$ indicated that this association was relatively strong. Likewise, the chi-squared test confirmed an association between educational level and the reason for participation by voting in the elections ( $p$-value $=0.003$, Cramér's $V=0.108$, contingency coefficient $=0.184)$.

In the general analysis, without considering demographic aspects, the strongest relationship for the conversation variable was found in the closest personal context (home). Nonetheless, when analyzing the gender variable, the most notable associations were found for men talking with friends ( $p$-value $=0.000$, Cramér's $V=0.137$, contingency coefficient $=0.136)$.

A somewhat weaker relationship ( $p$-value $=0.003$, contingency coefficient $=0.134$, Cramér's $V=0.135$ ) was found between gender and the reason for voting. A greater percentage of men than women voted because of arguments and program proposals (Graph 5), with this reason also standing out relative to other reasons for voting.

Finally, the weakest links were found between age and spreading information about the elections (contingency coefficient $=0.126$ ) and conversations about the campaign, with associations having strength below 0.100.

\section{Discussion and conclusions}

In accordance with findings of previous studies (Strömbäck; Shehata, 2010; Drew; Weaver, 2006), the present analysis indicates an association between public interest in the 2019 general election campaign and its coverage in the media. Specifically, evidence was found for associations between interest in the campaign and the type of medium used to obtain such information. The trends indicated that, the greater the interest shown by citizens, the more they followed the campaign through the (print or digital) press.

Regardless of the level of interest in information about the campaign, television was the medium most followed during the electoral process. The causal and reciprocal relationships noted by Strömbäck and Shehata (2019) between political interest and following the news through different media were reflected in a solid association between these two variables, markedly so in the case of television, especially for public broadcasters. Despite confirming the link between these variables, the present work also showed that the 2019 Spanish electoral campaign was followed more on television by those with lower interest in the campaign, while its use was also intensified among women and older citizens or those with a lower educational level. Certainly, television can reach large audiences with lower degrees of interest since it requires lower levels of effort and skill than other media such as the press in its paper or digital form (Schoenback; Lauf, 2002).

Conversation in family settings was the participation formula most related to the interest in the electoral process 
This trend for a high following among audiences with a low level of interest was also observed (albeit to a lesser extent) in the case of social networks. These reached special prominence among the younger population (González-Oñate; Jiménez-Marín; Sanz-Marcos, 2020) and as a secondary source of information for people with lower levels of interest. In this sense, the IAB Spain report on the use of social networks in 2021 confirmed their greater use among the young population but a limited following (18\%) of the accounts of politicians or media (31\%), compared with their broad use as a tool to follow information from friends or acquaintances (92\%), influencers or brands $(48 \%)$.

Those who showed the greatest interest stayed informed mainly through the press, which has also been found to be a medium that stimulates political interest (Boulianne, 2011). In the case of Spain, Fraile (2011) found associations between reading newspapers and higher political knowledge, while the results for radio were mixed and those for television insignificant.

On television, the debate showed a high following, particularly among those with a high level of interest in the campaign. Nonetheless, it had a very weak impact on their voting intention. These results support claims about the difficulty of demonstrating the effects of debates on voting intention, and their greater utility for reinforcement than contributing to any change (Jamieson; Adasiewicz, 2000, pp. 25-42). In the particular case of RTVE's social networks, Fontenla-Pedreira; Rúas-Araújo; Puentes-Rivera (2020) highlight the lack of interactivity between audiences and profiles, as well as the very low level of debate among users themselves. In relation to previous research (Norris, 2000; Kaufhold; Valenzuela; Gil de Zúñiga, 2010; Gil de Zúñiga; Ardèvol-Abreu; Casero-Ripollés, 2019), the present study confirms the associations between interest in information and civic participation. Nonetheless, it also reveals interesting differences between the studied forms of participation. In particular, levels of conversation, voting, and spreading information clearly presented solid links with interest in the 2019 Spanish electoral campaign (Cho et al., 2009; Weeks et al., 2017). Conversations in the family setting were the form of participation most strongly related to interest in the campaign, although men and people with higher educational levels showed a preference for conversations about the campaign with their friends. The association of participation through voting based on program proposals did not reach significance, with the male vote being the most strongly determined by electoral proposals presented during the campaign.

The strongest relationships regarding the demographic variables were observed for educational level, interest in the campaign, keeping abreast of information, and participation. People with higher educational levels showed greater interest in the campaign and following information about it, especially through the press and radio, while television was the medium most used by those with lower levels of education. Furthermore, people with higher educational levels used social networks to a lesser extent, which seems to indicate that interest plays a key role in the use of these platforms as an information source. Furthermore, Grabe, Kamhawi, and Yegiyan (2009) showed that people with lower educational levels better encode, store, and retrieve information from television news but have lower memory capacity for newspaper news. In line with previous findings (Verba; Schlozman; Brady, 1995; Oser; Hooge; Marien, 2013), participation increased with the educational level of citizens.

A particular result of this research is that those who participated most were those with higher educational levels, and that they did so especially through conversations with friends and by spreading electronic information related to the campaign. This form of intersubjective participation is aided by the emergence of digital spaces that encourage conversations in a more segmented way. The implication is that, despite the multiplicity of conversation groups, segmentation can lead to a standardized form of discourse within each group due to the common motivations of its members (Copeland; Feezall, 2017).

The conclusions of this work provide starting points for further research, such as in-depth study on the effects of education on interest in and following political information, or detailed studies on the associations established for different types of online platform.

\section{References}

Ackerman, Bruce; Fishkin, James S. (2004). “Deliberation day". In: Fishkin, James S.; Laslett, Peter (eds.). Debating deliberative democracy. Oxford: Blackwell Publishing, pp. 7-30. ISBN: 9781405100427

https://doi.org/10.1002/9780470690734.ch1

Anscombe, Frank J. (1973). “Graphs in statistical analysis”. American statistician, v. 27, n. 1, pp. 17-21. https://doi.org/10.2307/2682899

Ardèvol-Abreu, Alberto; Barnidge, Mathew; Gil de Zúñiga, Homero (2017). "Communicative antecedents of political persuasion: political discussion, citizen news creation and the moderating role of strength of partisanship". Mass communication and society, v. 20, n. 2, pp. 169-191.

https://doi.org/10.1080/15205436.2016.1244855

Baumgartner, Frank R.; Chaqués-Bonafont, Laura (2015). "All news is bad news: newspaper coverage of political parties in Spain". Political communication, v. 32, n. 2, pp. 268-291.

https://doi.org/10.1080/10584609.2014.919974 
Benoit, William L. (2017). "Meta-analysis of research on the functional theory of political campaign discourse". Speaker \& gavel, v. 54, n. 1, pp. 7-50.

https://bit.ly/36LMklz

Benoit, Willilam L.; Benoit-Bryan, Jennifer M. (2013). "Debates come to the United Kingdom: a functional analysis of the 2010 British prime minister election debates". Communication quarterly, v. 61, n. 4, pp. 463-478.

https://doi.org/10.1080/01463373.2013.799513

Boulianne, Shelley (2011). "Stimulating or reinforcing political interest: using panel data to examine reciprocal effects between news media and political interest". Political communication, v. 28, n. 2, pp. 147-162.

https://doi.org/10.1080/10584609.2010.540305

Boulianne, Shelley (2018). "Twenty years of digital media effects on civic and political participation". Communication research, v. 47, n. 7, pp. 947-966.

https://doi.org/10.1177/0093650218808186

Casero-Ripollés, Andreu; Feenstra, Ramón A.; Tormey, Simon (2016). “Old and new media logics in an electoral campaign: the case of Podemos and the two-way street mediatization of politics". The international journal of press/politics, v. 21, n. 3, pp. 378-397.

https://doi.org/10.1177/1940161216645340

Cho, Jaeho; Shah, Dhavan V.; McLeod, Jack M.; McLeod, Douglas M.; Scholl, Rosanne M.; Gotlieb, Melisa R. (2009). "Campaigns, reflection and deliberation: advancing an O-S-R-O-R model of communication effects". Communication theory, v. 19, n. 1, pp. 66-88.

https://doi.org/10.1111/j.1468-2885.2008.01333.x

CIS (2020). Barómetro de diciembre 2019. Postelectoral elecciones generales 2019. Madrid: Centro de Investigaciones Sociológicas.

https://bit.ly/2YMqPfT

Copeland, Lauren; Feezell, Jessica T. (2017). "The influence of citizenship norms and media use on different modes of political participation in the US". Political studies, v. 65, n. 4, pp. 805-823.

https://doi.org/10.1177/0032321717720374

Cramér, Harald (1946). Mathematical methods of statistics. Princeton: Princeton University Press. ISBN: 9780691005478 https://doi.org/10.1515/9781400883868

Drew, Dan; Weaver, David (2006). “Voter learning in the 2004 presidential election: did the media matter?”. Journalism \& mass communication quarterly, v. 83, n. 1, pp. 25-42.

https://doi.org/10.1177/107769900608300103

Druckman, James N.; Parkin, Michael (2005). "The impact of media bias: how editorial slant affects voters". Journal of politics, v. 67, n. 4, pp. 1030-1049.

https://doi.org/10.1111/j.1468-2508.2005.00349.x

Fontenla-Pedreira, Julia; Rúas-Araújo, José; Puentes-Rivera, Iván (2020). “El debate electoral de las elecciones generales del 10N de 2019 en las redes sociales de RTVE". Profesional de la información, v. 29, n. 6, e290603.

https://doi.org/10.3145/epi.2020.nov.03

Fraile, Marta (2011). "Widening or reducing the knowledge gap? Testing the media effects on political knowledge in Spain (2004-2006)". The international journal of press/politics, v. 16, n. 2, pp. 163-184.

https://doi.org/10.1177/1940161210388413

Gerth; Matthias A.; Siegert, Gabriele (2012). "Patterns of consistence and constriction: how news media frame the coverage of direct democratic campaigns". American behavioral scientist, v. 56, n. 3, pp. 279-299.

https://doi.org/10.1177/0002764211426326

Gil de Zúñiga, Homero; Ardèvol-Abreu, Alberto; Casero-Ripollés, Andreu (2019). “WhatsApp political discussion, conventional participation and activism: exploring direct, indirect and generational effects". Information, communication \& society, v. 24, n. 2, pp. 201-218.

https://doi.org/10.1080/1369118X.2019.1642933

Gingrich, Paul (1992). Introductory statistics for the social sciences. Department of sociology and social sciences, University of Regina.

https://bit.ly/3q88S7q

González-Neira, Ana; Berrocal-Gonzalo, Salomé; Zamora-Martínez, Patricia (2020). "Fórmulas de emisión y consumo de los debates televisivos en España en las elecciones legislativas de 2019". Profesional de la información, v. 29, n. 2, e290221. https://doi.org/10.3145/epi.2020.mar.21 
González-Oñate, Cristina; Jiménez-Marín, Gloria; Sanz-Marcos, Paloma (2020). "Consumo televisivo y nivel de interacción y participación social en redes sociales: análisis de las audiencias millennials en la campaña electoral de España". Profesional de la información, v. 29, n. 5, e290501.

https://doi.org/10.3145/epi.2020.sep.01

Gottfried, Jeffrey A.; Hardy, Bruce W.; Holbert, R. Lance; Winneg, Kenneth M.; Jamieson, Katheleen-Hall (2017). "The changing nature of political debate consumption: social media, multitasking and knowledge acquisition". Political communication, v. 34, n. 2, pp. 172-199.

https://doi.org/10.1080/10584609.2016.1154120

Grabe, Maria-Elizabeth; Kamhawi, Rasha; Yegiyan, Narine (2009). "Informing citizens: how people with different levels of education process television, newspaper and web news”. Journal of broadcasting \& electronic media, v. 53, n. 1, pp. $90-111$. https://doi.org/10.1080/08838150802643860

Hansen, Kasper M.; Pedersen, Rasmus-Tue (2014). "Campaigns matter: how voters become knowledgeable and efficacious during election campaigns". Political communication, v. 31, n. 2, pp. 303-324.

https://doi.org/10.1080/10584609.2013.815296

Hopmann, David N.; Wonneberger, Anke; Shehata, Adam; Höijer, Jonas (2016). "Selective media exposure and increasing knowledge gaps in Swiss referendum campaigns". International journal of public opinion research, v. 28, n. 1, pp. 73-95. https://doi.org/10.1093/ijpor/edv002

Humanes, María-Luisa (2014). “Exposición selectiva y partidismo de las audiencias en España. El consumo de información política durante las campañas electorales de 2008 y 2011”. Palabra clave, v. 17, n. 3, pp. 773-802.

https://doi.org/10.5294/pacla.2014.17.3.9

IAB Spain (2021). Estudio de redes sociales 2021.

https://iabspain.es/estudio/estudio-de-redes-sociales-2021

Jamieson, Kathleen-Hall; Adasiewicz, Christopher (2000). “What can voters learn from election debates?”. In: Coleman, Stephen (ed.). Televised election debates: International perspectives. London: Palgrave Macmillan, pp. 25-42. ISBN: 978 0230379602 https://doi.org/10.1057/9780230379602_2

Kaufhold, Kelly; Valenzuela, Sebastián; Gil de Zúñiga, Homero (2010). “Citizen journalism and democracy: how user generated new use relates to political knowledge and participation". Journalism and mass media communication quarterly, v. 87 , n. $3 / 4$, pp. 515-529.

https://doi.org/10.1177/107769901008700305

Lago-Vázquez, Diana; Direito-Rebollal, Sabela; Rodríguez-Vázquez, Ana-Isabel; López-García, Xosé (2016). “El consumo millennial de información política en televisión y redes sociales. Análisis de la campaña elecciones generales en España 2015". Revista latina de comunicación social, n. 71, pp. 1151-1169.

https://doi.org/10.4185/rlcs-2016-1139

Lazarsfeld, Paul F.; Berelson, Bernard; Gaudet, Hazel (1948). The people's choice. How the voter makes up his mind in a presidential campaign. New York Chichester, West Sussex: Columbia University Press. ISBN: 9780231896146 https://doi.org/10.7312/laza93930

López-García, Guillermo; Llorca-Abad, Germán; Valera-Ordaz, Lidia; Peris-Blanes, Alvar (2018). "Los debates electorales, ¿̇el último reducto frente la mediatización? Un estudio de caso de las elecciones generales españolas de 2015". Palabra clave, v. 21, n. 3, pp. 772-797.

https://doi.org/10.5294/pacla.2018.21.3.6

Madianou, Mirca; Miller, Daniel (2013). "Polymedia: towards a new theory of digital media in interpersonal communication". International journal of cultural studies, v. 16, n. 2, pp. 169-187.

https://doi.org/10.1177/1367877912452486

Moeller, Judith; De-Vreese, Claes; Esser, Frank; Kunz, Ruth (2014). "Pathway to political participation: the influence of online and offline news media on internal efficacy and turnout of first-time voters". American behavioral scientist, v. 58, n. 5, pp. 689-700.

https://doi.org/10.1177/0002764213515220

Mondak, Jeffery J. (2010). Personality and the foundations of political behavior. Cambridge: Cambridge University Press. ISBN: 9780521140959

https://doi.org/10.1017/CB09780511761515.001

Müller, Stefan (2020). "Media coverage of campaign promises throughout the electoral cycle”. Political communication, v. 37, n. 5 , pp. 696-718.

https://doi.org/10.1080/10584609.2020.1744779 
Norris, Pippa (2000). A virtuous circle. Political communications in postindustrial societies. Cambridge: Cambridge university press. ISBN: 9780511609343

https://doi.org/10.1017/CBO9780511609343

Oser, Jennifer; Hooghe, Marc; Marien, Sophie (2013). "Is online participation distinct from offline participation? A latent class analysis of participation types and their stratification”. Political research quarterly, v. 66, n. 1, pp. 91-101. https://doi.org/10.1177/1065912912436695

Pont-Sorribes, Carles; Besalú, Reinald; Codina, Lluís (2020). “WhatsApp como canal de información política en España: credibilidad, perfil de usuarios y compartición de contenidos". Profesional de la información, v. 29, n. 6, e290619.

https://doi.org/10.3145/epi.2020.nov.19

Schoenback, Klaus; Lauf, Edmund (2002). "The 'trap' effect of television and its competitors". Communication research, v. 29 , n. 5 , pp. 564-583.

https://doi.org/10.1177/009365002236195

Soroka, Stuart N. (2012). "The gatekeeping function: Distributions of information in media and the real world". The journal of politics, v. 74, n. 2, pp. 514-528.

https://doi.org/10.1017/S002238161100171X

Soroka, Stuart N.; Wlezien, Christopher (2019). "Tracking the coverage of public policy in mass media". Policy studies journal, v. 47, n. 2, pp. 471-491.

https://doi.org/10.1111/psj.12285

Strömbäck, Jesper (2008). "Four phases of mediatization: an analysis of the mediatization of politics". The international journal of press/politics, v. 13, n. 3, pp. 228-246.

https://doi.org/10.1177/1940161208319097

Strömbäck, Jesper; Dimitrova, Daniela V. (2011). “Mediatization and media interventionism: A comparative analysis of Sweden and the United States". The international journal of press/politics, v. 16, n. 1, pp. 30-49.

https://doi.org/10.1177/1940161210379504

Strömbäck, Jesper; Djerf-Pierre, Monika; Shehata, Adam (2016). "A question of time? A longitudinal analysis of the relationship between news media consumption and political trust". The international journal of press/politics, v. 21, n. 1, pp. 88-110. https://doi.org/10.1177/1940161215613059

Strömbäck, Jesper; Shehata, Adam (2010). "Media malaise or a virtuous circle? Exploring the causal relationships between news media exposure, political news attention and political interest". European journal of political research, v. 49, n. 5, pp. 575-597.

https://doi.org/10.1111/j.1475-6765.2009.01913.x

Strömbäck, Jesper; Shehata, Adam (2019). "The reciprocal effects between political interest and TV news revisited: Evidence from four panel surveys". Journalism and mass communication quarterly, v. 96, n. 2, pp. 473-496.

https://doi.org/10.1177/1077699018793998

Van-Aelst, Peter; Strömbäck, Jesper; Aalberg, Toril; Esser, Frank; De-Vreese, Claes; Matthes, Jörg; Hopmann, David; Salgado, Susana; Hubé, Nicolas; Stępińska, Agnieszka; Papathanassopoulos, Stylianos; Berganza, Rosa; Legnante, Guido; Reinemann, Carsten; Sheafer, Tamir; Stanyer, James (2017). "Political communication in a high-choice media environment: A challenge for democracy?". Annals of the international communication association, v. 41, n. 1, pp. 3-27. https://doi.org/10.1080/23808985.2017.1288551

Verba, Sidney; Schlozman, Kay-Lehman; Brady, Henry E. (1995). Voice and equality: Civic voluntarism in American politics. Harvard University Press. ISBN: 9780674942936

Vinson, C. Danielle; Moore, William V. (2007). "The campaign disconnect: media coverage of the 2000 South Carolina presidential primary". Political communication, v. 24, n. 4, pp. 393-413.

https://doi.org/10.1080/10584600701641540

Walgrave, Steefan; Soroka, Stuart N.; Nuytemans, Michiel (2008). “The mass media's political agenda setting power: A longitudinal analysis of media, parliament, and government in Belgium (1993 to 2000)". Comparative political studies, v. 41, n. 6 , pp. $814-836$.

https://doi.org/10.1177/0010414006299098

Weeks, Brian E.; Lane, Daniel S.; Kim, Dam-Hee; Lee, Slgi S.; Kwak, Nojin (2017). "Incidental exposure, selective exposure, and political information sharing: Integrating online exposure patterns and expression on social media". Journal of computer-mediated communication, v. 22, n. 6, pp. 363-379.

https://doi.org/10.1111/jcc4.12199 